\title{
JNVEST[GHACJÓN
}

\section{Preparation and evaluation of sulphonamide nonionic surfactants}

\author{
By M. H. M. Ahmed
}

\author{
Chemistry Department, Faculty of Science, Benha University, Benha, Egypt \\ (Corresponding author: ahmedmh11@yahoo.com)
}

\begin{abstract}
RESUMEN
Preparación y evaluación de surfactantes no iónicos tipo sulfonamidas

Cloruros de sulfonilbenceno alquilados (octil, decil, dodecil; $\mathrm{C}_{8}, \mathrm{C}_{10}$ y $\mathrm{C}_{12}$ ) fueron usados en la preparación de una nueva serie de surfactantes no iónicos (IV-VI)a-c, (VII-IX) a-c and (X-XII)a-c. Las preparaciones fueron completadas por reacción de cada cloruro de sulfonilbenceno alquilado $\left(\mathrm{C}_{8}, \mathrm{C}_{10}\right.$ y $\left.\mathrm{C}_{12}\right)$ con etanolamina para dar los compuestos (IIII), respectivamente. Los anteriores productos reaccionaron separadamente con óxido de etileno en presencia de diferentes catalizadores (la base $\mathrm{KOH}$, el ácido de Lewis $\mathrm{SnCl}_{4}$ y la arcilla k10) para producir secuencialmente diferentes surfactantes no iónicos con distintos moles de óxido de etileno $(5,7$ y 9): (IV-VI)a-c, (VII-IX)a-c and (X-XII)a-c, respectivamente. La estructura química de los surfactantes no iónicos preparados fueron elucidadas mediante sus espectros de IR y ${ }^{1} \mathrm{H}$ RMN. Las propiedades tensoactivas, biodegradabilidad y actividad biológica de los compuestos preparados fueron investigados. Los datos obtenidos muestran que estos compuestos tienen buenas propiedades tensoactivas y biológicas, así como una biodegradabilidad razonable.
\end{abstract}

PALABRAS-CLAVE: Actividad biológica - Catalizador de arcilla K10 - Propiedades tensoactivas - Surfactante no iónico.

\section{SUMMARY}

Preparation and evaluation of sulphonamide nonionic surfactants

Alkyl (octyl, decyl and dodecyl; $\mathrm{C}_{8}, \mathrm{C}_{10}$ and $\mathrm{C}_{12}$ ) benzene sulphonyl chloride was used in the preparation of a novel series of nonionic surfactants (IV-VI)a-c, (VII-IX) a-c and (X-XII)a-c. The preparations were completed by reacting each alkyl $\left(C_{8}, C_{10}\right.$ and $\left.C_{12}\right)$ benzene sulphonyl chloride with ethanolamine to give (I-III) respectively. The resulting products were reacted separately with ethylene oxide in the presence of different (base $\mathrm{KOH}$, Lewis acid $\mathrm{SnCl}_{4}$ and k10 clay) catalysts to produce different moles of nonionic surfactants $(5,7$ and 9$)$ in sequence corresponding to (IV-VI)a-c, (VII-IX) a-c and (X-XII)a-c respectively. The chemical structures of prepared nonionic surfactants were elucidated by IR and ${ }^{1} \mathrm{HNMR}$ spectra. The surface activity, biodegradability and biological activities of the prepared compounds were investigated. The obtained data show that these compounds have good surface and biological activities as well as reasonable biodegradability properties.

KEY-WORDS: Biological activity - Nonionic surfactant K10 clay catalyst - Surface activity.

\section{INTRODUCTION}

Nonionic surfactant is one of the most important groups of surfactant with growing industrial interest and can be synthesized by the ethoxylation (addition of ethylene oxide) of hydrophobic organic compounds containing active hydrogen in the presence of a traditional catalyst (basic catalysts, e.g. $\mathrm{NaOH}$, or Lewis acids e.g. $\mathrm{BF}_{3}$, e.t.c. (Schonfeld, 1967; Fainerman et al., 2001), rather than an untraditional catalyst e.g. different clays, calcium compound, e.t.c.) (Sallay et al., 1997; Herczuch et al., 2001).

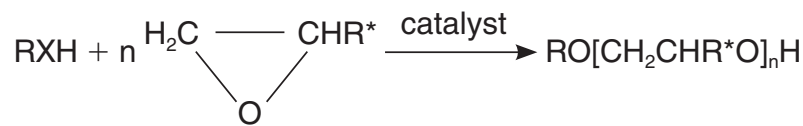

Where: $\mathrm{R}$ is a log chain aliphatic hydrocarbon, alkyl phenyl, aralkyl group $\mathrm{XH}$ is $\mathrm{OH}, \mathrm{SH}, \mathrm{COOH}, \mathrm{NH}$, e.t.c. $\mathrm{R}^{*}$ is $\mathrm{H}$ (ethoxylation) or $\mathrm{CH}_{3}$ (propoxylation); $\mathrm{n}$ is moles of alkylene oxide reacted with one mole of starting material.

The product of ethoxylation is a mixture of oligo(poly)ethylene glycol ethers. Therefore the properties of nonionic depend on the ethylene oxide added (average degree of ethoxylation, types of starting material and the type of catalysts used (Nico, 1998). Ethoxylation is a process extensively used by the industry to produce a large number of nonionic products. An important class of such products is polys (ethylene glycol) produced with untraditional catalysts, which are industrially preferred and largely used as final or chemical intermediates, lubricants, industrial surfactants, and components 
for cosmetics and personal care formulations (Bailey and Joseph, 1991).

The hydrophilic group generally is a oligo(poly) ethylene glycol chain with a free hydroxyl or amino group at the end of the molecule. The Hydrophobic group is usually a long chain of the fatty alcohol, acids or alkylphenol, aralkyl alcohols (Ahmed et al., 2002).

Sulphonamide surfactants are a very important industrial domain due to the fact that these compounds possess a combination of efficiency, biological activity and biodegradability (Maria and Holmberg, 2005). The presence of the $-\mathrm{SO}_{2} \mathrm{NH}$ function demonstrates good biodegradability. They were synthesized from the reaction of alkanesulfonyl chlorides with primary or secondary amine, or ammonia (Mousli and Amel, 2007; Azira et al., 2003; Assassi et al., 2006). Therefore, these compounds possess good surface properties and have been recommended as synthetic industrial detergents and as an intermediate in agricultural and chemical manufacturing. They are also used, among other things, in the treatment of textiles and paper and even as an inhibitor of corrosion (Sandler and Hemlock, 1989; Sandler, 1991; Braun et al., 1986).

The aim of this work was to prepare sulphonamide nonionic surfactants from treated oils. Alkyl benzene sulphonyl chloride is one of the most popular and inexpensive materials used in the synthesis of a large number of surface active agents, using traditional $\left(\mathrm{KOH}\right.$, Lewis acid $\left.\mathrm{SnCl}_{4}\right)$ and untraditional catalysts (K10 clay)., The prepared compounds contain a sulphonamide group which have biological activity besides surface active properties. The prepared compounds are prepared according the following reactions (Scheme 1).

\section{MATERIALS AND METHODS}

\subsection{Materials}

Alkyl benzene sulphonic chloride (99\%, HPLC) supplied from the Naser company; ethanolamine (Aldrich); ethylene oxide (Purity $99 \%$ ); KOH Reanal reagent; $\mathrm{SnCl}_{4}$ Merck reagent and $\mathrm{K} 10$ clay (Sallay et al., 1997) were used.

\subsection{Methods}

The structures of the synthesized compounds were confirmed by infrared (IR), nuclear magnetic resonance ( $\left.{ }^{1} \mathrm{H} \mathrm{NMR}\right)$.

\section{Infrared absorption spectroscopy}

The qualitative infrared absorption spectra of the synthesized compounds were recorded on a Beckmon 4220 spectrophotometer.

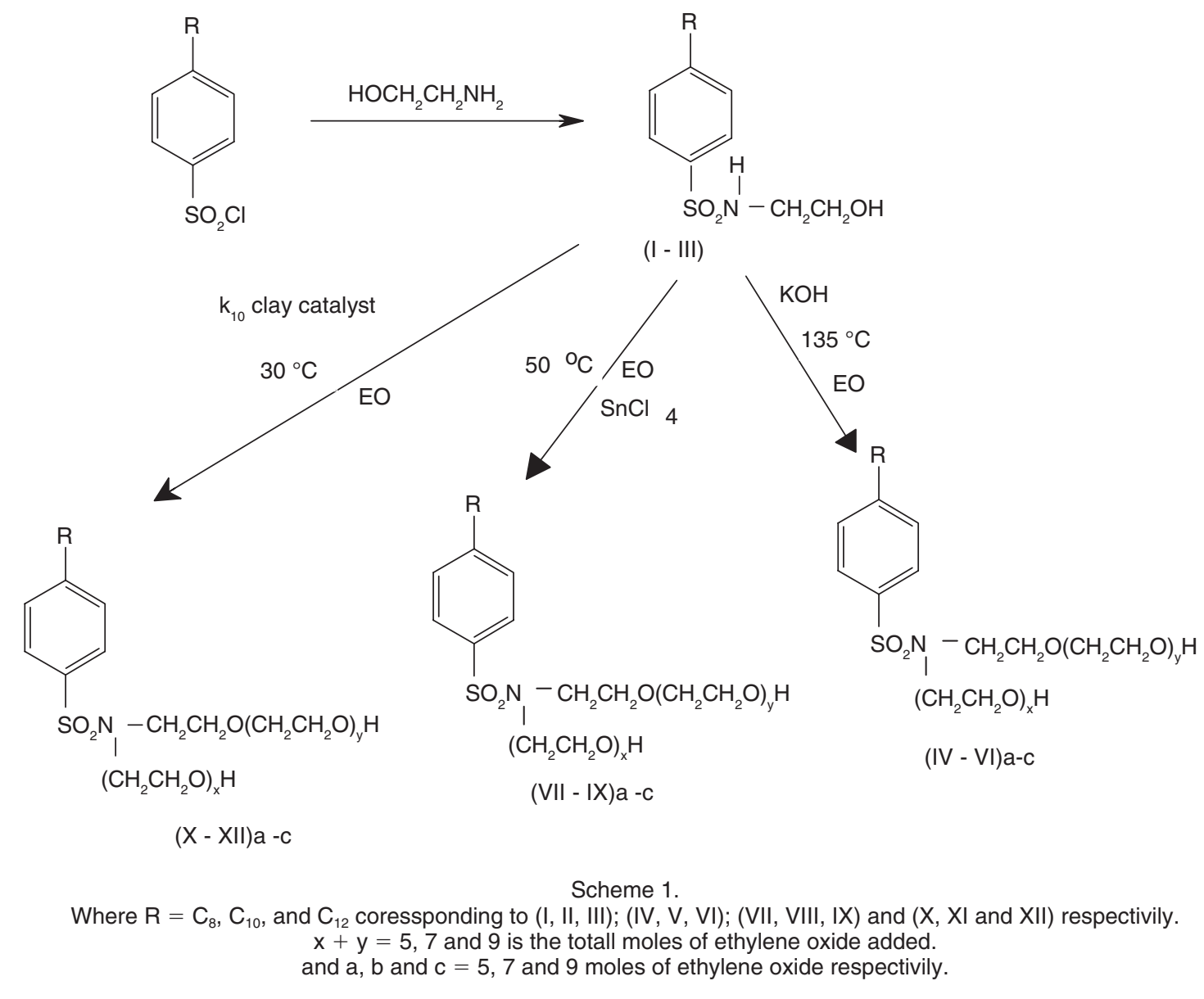




\section{Nuclear magnetic resonance (1HNMR)}

The ${ }^{1}$ HNMR spectra of the compounds under investigation have been recorded in deuterated chloroform $\left(\mathrm{CDCl}_{3}\right)$ and /or in (DMSO) as a solvent and tetramethyl silane (TMS) as an internal reference with a $90 \mathrm{MHz}$ signal and 4.000 gauss magnetic field.

\subsection{Preparation of nonionic surfactants (IV-VI) a-c to (X-XII)a-c}

Preparation of N(2-hydroxyethyl)alkyl benzene sulphonamide (I-III).

\section{Example preparation of III}

(0.01 mole, $3.29 \mathrm{~g}$ ) of dodecyl benzene sulphonyl chloride, 0.01 mole, $0.61 \mathrm{~g}$ ) of ethanolamine, $50 \mathrm{ml}$ of dry benzene and drops of pyridine were stirred in a reflux condenser for $2 \mathrm{hrs}$, cooled and poured into acidified ice/water. The products were extracted with chloroform, dried with anhydrous $\mathrm{Na}_{2} \mathrm{SO}_{3}$. The solvent was then evaporated and the crude product (III) was obtained. The product was crystallized using petroleum ether 60-80. The reaction molar ratios and the product characterization for three products are presented in Table 1.

\section{Ethoxylation}

Ethoxylation was carried out as described in (Sallay et al., 2000), and the amount of ethylene oxide consumption (ADE) was determined from the increase in the weight of the reaction mixture and was controlled by spectroscopic tools (Ahmed et al., 1996). The conditions of the ethoxylation process and the reaction characterizations are presented in Table 2.

\subsection{Determination of the performance properties of prepared nonionic surfactants}

All these products were investigated under neutral conditions in an aqueous phase using oily and semisolid (cream matter), the investigated solutions were prepared at room temperature.

\section{Surface and interfacial tensions}

Surface and interfacial tensions were measured in a 0.1 wt $\%$ aqueous solution at room temperature $\left(25^{\circ} \mathrm{C}\right)$ using a DU-NOUY tension meter (KRUSS type 8451) (Findely 1963).The interfacial tension was measured using paraffin oil

\section{Cloud point}

The cloud point, measured as the inverse solubility characteristic of nonionic surface active agents, was determined by gradually heating 1.0 wt $\%$ solution in a controlled temperature bath and recording the temperature at which the clear or

Table 1

Reaction conditions and product characterization of (I- III)

\begin{tabular}{ccccc}
\hline Compound & $\begin{array}{c}\text { Alkyl (C8, C10 and C12) } \\
\text { Sulphonamide chloride (g. mole) }\end{array}$ & $\begin{array}{c}\text { Ethanolamine } \\
\text { g. mole }\end{array}$ & $\begin{array}{c}\text { Product } \\
\text { g. mole }\end{array}$ & $\begin{array}{c}\text { Yield } \\
\%\end{array}$ \\
\hline I; $C_{8}$ & $(2.73,0.01)$ & $(0.61,0.01)$ & $\begin{array}{c}\text { Light brown cream* } \\
(2.8,0.0097)\end{array}$ & 96.9 \\
II; $C_{10}$ & $(3.00,0.01)$ & $(0.61,0.01)$ & $\begin{array}{c}\text { Pale brown cream } \\
(2.9,0.0092)\end{array}$ & 93.5 \\
III; $C_{12}$ & $(3.29,0.01)$ & $(0.61,0.01)$ & $\begin{array}{c}\text { Yellow white Cream* } \\
(3.0,0.0085)\end{array}$ & 90.3 \\
\hline
\end{tabular}

Solvent of crystallizations are:* petroleum ether $40-60{ }^{* *}$ Petroluem ether $60-80$

Table 2

Reaction conditions and product characterization of ethoxylated products

\begin{tabular}{|c|c|c|c|c|}
\hline $\begin{array}{l}\text { Starting substrate } \\
(0.02 \mathrm{~mole})\end{array}$ & $\mathbf{R}$ & Catalyst mol \% & Reaction temp. ${ }^{\circ} \mathbf{C}$ & $\begin{array}{c}\text { ADE } \\
\text { Mole / substrate }\end{array}$ \\
\hline I & 8 & \multirow{3}{*}{$\mathrm{KOH} ;(0.01)$} & \multirow{3}{*}{135} & \multirow{3}{*}{5,7 and $9(\mathrm{IV}-\mathrm{VI}) \mathrm{a}-\mathrm{C}$} \\
\hline II & 10 & & & \\
\hline III & 12 & & & \\
\hline 1 & 8 & \multirow{3}{*}{$\mathrm{SbCl}_{4} ;(0.01)$} & \multirow{3}{*}{50} & \multirow{3}{*}{5,7 and $9(\mathrm{VII}-\mathrm{IX}) \mathrm{a}-\mathrm{c}$} \\
\hline II & 10 & & & \\
\hline III & 12 & & & \\
\hline I & 8 & \multirow{3}{*}{ K10 clay $(0.01)$} & \multirow{3}{*}{30} & \multirow{3}{*}{5,7 and $9(X-X I I) a-c$} \\
\hline II & 10 & & & \\
\hline III & 12 & & & \\
\hline
\end{tabular}

ADE: Average degree of ethoxylation. 
nearly clear solutions became definitely turbid. Cooling the solutions until they became clear again confirmed the reproducibility of this temperature (Durham, 1961).

\section{Wetting time}

The wetting time of the prepared surfactants was determined by immersing a sample of cotton fabric in $1.0 \mathrm{wt} \%$ aqueous solution of the surfactants and measuring its sinking time in seconds (Cohen and Rosen, 1981).

\section{Foam and foam stability}

The foaming properties were determined according to (El-Sukkary et al., 1987). A $25 \mathrm{ml}$ solution (1.0 wt \%) was shaken 20 times up and down, in a $100 \mathrm{ml}$ closed graduated cylinder at $25^{\circ} \mathrm{C}$ and the foam volume was measured immediately. Foam stability was calculated by using the following formula (Saito et al., 1989):

Foam stability $(\%)=$ (foam volume after 5 minutes /foam volume after 0 minutes) $\times 100$.

\section{Emulsion stability}

The emulsion was prepared from $10 \mathrm{ml}$ of a 20 $\mathrm{m}$ mole aqueous solution of surfactant and $5 \mathrm{ml}$ of toluene at $40{ }^{\circ} \mathrm{C}$. Th e emulsifying properties were determined by the time it took for an aqueous volume separating from the emulsion layer to reach $9 \mathrm{ml}$ counting from the moment shaking was stopped (Takeshi, 1970).

\section{Biodegradability}

Die-away tests in river water were performed employing the surface tension method (Etre et al., 1974)] using DU-NOUY tension meter (KRUSS type 8451). Samples taken daily were filtered through No. 1 Whatman filter paper before measuring the surface tension. Biodegradation was calculated by the following equation:

$$
D=\gamma_{t}-\gamma_{0} / \gamma_{b t}-\gamma_{0}
$$

$\left(\gamma_{t}\right.$ : surface tension at time $t ; \gamma_{0}$ : surface tension at time zero (initial surface tension); $\gamma_{b t}$ : surface tension of the control sample at time $\mathrm{t}$ ).

\section{Biological Activity}

Antibacterial and antifungal activities of the synthesized compounds. The biological activities of these compounds have been evaluated by the wellplate methods (Egorov, 1965) (diffusion methods) which were followed with some modification. The example of the test organisms (gram negative bacterial- Escherichia coil-, gram positive bacteriastaphylococcus aureus and fungi- aspergillus niger-) was prepared and the test substances were dissolved in sterile water to make a solution of different concentrations $(0.25 \%, 0.5 \%, 1 \%$, and $2 \%$ ). Antimicrobial activities were observed after $48 \mathrm{hrs}$ of incubation time for bacteria at $37^{\circ} \mathrm{C}$, and after $72 \mathrm{hrs}$ of incubation time for fungi at $30^{\circ} \mathrm{C}$. The zones of inhibition were measured in $\mathrm{mm}$. Tables 8 and 9 represent the extent of the inhibition zone diameters in $\mathrm{mm}$.

\section{RESULTS AND DISCUSSION}

\subsection{Preparation and Structure Elucidation}

N-(2-hydroxyethyl) Alkyl (octyl, $C_{8}$ decyl, $C_{10}$ and dodecyl, C12) benzene sulphenoamide (I-III)

They were prepared by the reaction described above: akylbenzene sulphonyl chloride with ethanolamine in the presence of pyridine as a catalyst; the compounds (I-III) were obtained and their chemical structures were confirmed via IR and ${ }^{1} \mathrm{H}$ NMR spectra.

IR spectra in all prepared compounds (I-III) shows that the most characteristic IR bands are $\mathrm{v}_{\mathrm{NH}}$, in the region of $\left(3400-3320 \mathrm{~cm}^{-1}\right), \mathrm{v}_{\mathrm{OH}}$ in the region of $\left(3300-3230 \mathrm{~cm}^{-1}\right), v \mathrm{SO}_{2}$ at $\left(1070-1020 \mathrm{~cm}^{-1}\right)$, $v_{\mathrm{C}-\mathrm{H} \text { aromatic }}$ at $\left(3060-3010 \mathrm{~cm}^{-1}\right)$ and $\mathrm{v}_{\mathrm{C}-\mathrm{H} \text { aliphatic }}$ of alkyl chain in the region of $\left(2920-2850 \mathrm{~cm}^{-1}\right)$,

${ }^{1} \mathrm{H}$ NMR of $(\mathrm{I})$ shows signals: $\delta_{\mathrm{ppm}}$ at $0.9(\mathrm{t}, 3 \mathrm{H}$, terminal $\left.-\left(\mathrm{CH}_{2}\right)_{7} \mathrm{CH}_{3}\right) ; \delta_{\mathrm{ppm}}$ at 1.5-1.2 $(\mathrm{m}, 14 \mathrm{H}$, $\left(\mathrm{CH}_{2}\right)_{7} \mathrm{CH}_{3}$ of alkyl chain); $\delta_{\mathrm{ppm}}$ at 2.7-2.3 (t, $4 \mathrm{H}$, of $\left.\mathrm{SO}_{2} \mathrm{NHCH}_{2} \mathrm{CH}_{2} \mathrm{OH}\right) ; \delta_{\mathrm{ppm}}$ at $4.3(\mathrm{~s}, 2 \mathrm{H}, \underline{\mathrm{NH}}$ and $\mathrm{OH}$ ) and $\delta_{\mathrm{ppm}}$ at 7.8-7.4 (d.d, 4H, ArH).

Ethoxylation of compounds (I - III) to produce (IV - VI)a-c; (VII-IX)a-c and (X - XII)a-c

They were completed in a homogeneous medium using different catalysts $\left(\mathrm{KOH}, \mathrm{SnCl}_{4}\right.$ and $\mathrm{K} 10$ clay) to give average degrees of ethoxylation $(5,7$ and 9 moles $=a, b$ and $c)$ for all mentioned products (c. f. Table 2.). The chemical structures of prepared ethoxylated products were confirmed by IR and ${ }^{1}$ HNMR (c. f. Table 3.). It can be seen that, in general, the most characteristic bands appear in the IR spectrum ranging from 1150$1100 \mathrm{~cm}^{-1} \mathrm{v}$ of $\mathrm{CH}_{2} \mathrm{OCH}_{2}$ due to ethylene oxide (Ahmed et al., 1996) and $\mathrm{vSO}_{2}$ at 1070-1050 $\mathrm{cm}^{-1}$ beside $\mathrm{V} \mathrm{CH}$ aliphatic ranging 2950-2880 $\mathrm{cm}^{-1}$ and $\mathrm{vCH}$ aromatic ranging from 3100-3020 $\mathrm{cm}^{-1}$. and ${ }^{1} \mathrm{HNMR} \delta$ ppm 3.8-3.5 of $\left(\mathrm{CH}_{2} \mathrm{CH}_{2} \mathrm{O}\right)$; for all the prepared compounds due to the similarity in their structures. (c.f. Table 3.)

\subsection{Surface active properties of the prepared nonionic surfactants}

The surface active and related properties, including surface and interfacial tensions, cloud point, foaming height, wetting time, and emulsification properties 
Table 3

${ }^{1}$ HNMR and IR for some samples of the prepared nonionic surfactants

\begin{tabular}{|c|c|c|}
\hline Compd. No. & ${ }^{1} \mathrm{HNMR}\left(\delta=\mathrm{ppm}, \mathrm{CDCl}_{3}, 90 \mathrm{MHz}\right)$ & IR $\left(\mathrm{cm}^{-1}\right.$ \\
\hline $\begin{array}{l}\text { KOH. } \\
\text { Va: (C10, } 5 \text { EO) : }\end{array}$ & $\begin{array}{c}\delta 0.80\left(\mathrm{t}, 3 \mathrm{H} \text {,term. } \mathrm{CH}_{3}\right) ; \delta 1.7-1.2\left(\mathrm{~m}, 18 \mathrm{H},-9 \mathrm{CH}_{2} \text {-chain): }\right. \\
\delta 2.4-2.2\left(\mathrm{~m}, 4 \mathrm{H},-\mathrm{N}^{-} \mathrm{CH}_{2} \mathrm{CH}_{2}-\mathrm{O}\right) ; \\
\delta 3.8-3.5\left(\mathrm{~m}, 2 \mathrm{H}, 5\left(\mathrm{CH}_{2} \mathrm{CH}_{2} \mathrm{O}\right) ; 7.8-7.4(\mathrm{~m}, 4 \mathrm{H}, \mathrm{ArH})\right. \\
\text { and } 4.3(\mathrm{~s}, 2 \mathrm{H}, \mathrm{OH})\end{array}$ & $\begin{array}{l}2890-2880 \mathrm{~cm}^{-1} v \mathrm{CH} \text { ali. } \\
3080-3020 \mathrm{~cm}^{-1} v \mathrm{CH} \text { of arom. } \\
1120-1100 \mathrm{~cm}^{-1} v \text { of } \mathrm{CH}_{2} \mathrm{OCH}_{2} \\
\mathrm{vSO}_{2} \text { at } 1050-1020 \mathrm{~cm}^{-1} \\
3500-3400 \mathrm{~cm}^{-1} v \mathrm{OH} .\end{array}$ \\
\hline VIc: (C12, 9 EO) : & $\begin{array}{c}\delta 0.90\left(\mathrm{t}, 3 \mathrm{H}, \text { term. } \mathrm{CH}_{3}\right) ; \delta 1.7-1.3\left(\mathrm{~m}, 22 \mathrm{H},-11 \mathrm{CH}_{2} \text {-chain }\right): \\
\delta 2.6-2.3\left(\mathrm{~m}, 4 \mathrm{H},-\mathrm{N}-\mathrm{CH}_{2} \mathrm{CH}_{2}-\mathrm{O}\right) ; \\
\delta 3.8-3.5\left(\mathrm{~m}, 36 \mathrm{H}, 9\left(\mathrm{CH}_{2} \mathrm{CH}_{2} \mathrm{O}\right) ; 7.8-7.4(\mathrm{~m}, 4 \mathrm{H}, \mathrm{ArH}) .\right. \\
\text { and } 4.4(\mathrm{~s}, 2 \mathrm{H}, \mathrm{OH})\end{array}$ & $\begin{array}{l}2920-2880 \mathrm{~cm}^{-1} v \mathrm{CH} \text { ali. } \\
3080-3010 \mathrm{~cm}^{-1} v \mathrm{CH} \text { of arom. } \\
1150-1100 \mathrm{~cm}^{-1} v \text { of } \mathrm{CH}_{2} \mathrm{OCH}_{2} \\
\mathrm{vSO}_{2} \text { at } 1070-1030 \mathrm{~cm}^{-1} \\
3450-3400 \mathrm{~cm}^{-1} v \mathrm{OH} \text {. }\end{array}$ \\
\hline $\begin{array}{l}\mathrm{SnCl}_{4} . \\
\text { VIIb: (C8, } 7 \text { EO): }\end{array}$ & $\begin{array}{c}\delta 0.80\left(\mathrm{t}, 3 \mathrm{H} \text {,term. } \mathrm{CH}_{3}\right) ; \delta 1.6-12\left(\mathrm{~m}, 14 \mathrm{H},-7 \mathrm{CH}_{2} \text {-chain): }\right. \\
\delta 2.5-2.3\left(\mathrm{~m}, 4 \mathrm{H},-\mathrm{N}^{-} \mathrm{CH}_{2} \mathrm{CH}_{2}-\mathrm{O}\right) ; \\
\delta \text { 3.7-3.4 (m, 28H, } 7\left(\mathrm{CH}_{2} \mathrm{CH}_{2} \mathrm{O}\right) ; 7.8-7.4(\mathrm{~m}, 4 \mathrm{H}, \mathrm{ArH}) . \\
\text { and } 4.4(\mathrm{~s}, 2 \mathrm{H}, \mathrm{OH})\end{array}$ & $\begin{array}{l}2890-2880 \mathrm{~cm}^{-1} v \mathrm{CH} \text { ali. } \\
3080-3020 \mathrm{~cm}^{-1} v \mathrm{CH} \text { of arom. } \\
1120-1100 \mathrm{~cm}^{-1} v \text { of } \mathrm{CH}_{2} \mathrm{OCH}_{2} \\
\mathrm{SSO}_{2} \text { at } 1070-1020 \mathrm{~cm}^{-1} \\
3400-3300 \mathrm{~cm}^{-1} v \mathrm{OH} .\end{array}$ \\
\hline IXb: (C12, 7 EO) : & $\begin{array}{c}\delta 0.90\left(\mathrm{t}, 3 \mathrm{H} \text {,term. } \mathrm{CH}_{3}\right) ; \delta 1.7-1.3\left(\mathrm{~m}, 22 \mathrm{H},-11 \mathrm{CH}_{2} \text {-chain): }\right. \\
\delta 2.5-2.3\left(\mathrm{~m}, 4 \mathrm{H},-\mathrm{N}-\mathrm{CH}_{2} \mathbf{C H}_{2}-\mathrm{O}\right) ; \\
\delta \text { 3.6-3.2 }\left(\mathrm{m}, 28 \mathrm{H}, 7\left(\mathrm{CH}_{2} \mathrm{CH}_{2} \mathrm{O}\right) ; 7.8-7.3(\mathrm{~m}, 4 \mathrm{H}, \mathrm{ArH}) .\right. \\
\text { and 4.4-4.2 (s, 2H, OH })\end{array}$ & $\begin{array}{l}2920-2880 \mathrm{~cm}^{-1} v \mathrm{CH} \text { ali. } \\
3080-3010 \mathrm{~cm}^{-1} v \mathrm{CH} \text { of arom. } \\
1150-1120 \mathrm{~cm}^{-1} v \text { of } \mathrm{CH}_{2} \mathrm{OCH}_{2} \\
\mathrm{vSO}_{2} \text { at } 1060-1030 \mathrm{~cm}^{-1} \\
3500-3400 \mathrm{~cm}^{-1} v \mathrm{OH} \text {. }\end{array}$ \\
\hline $\begin{array}{l}\text { Clay K10 } \\
\text { Xc: }(C 8,9 \text { EO) : }\end{array}$ & $\begin{array}{c}\delta 0.80\left(\mathrm{t}, 3 \mathrm{H} \text {,term. } \mathrm{CH}_{3}\right) ; \delta 1.7-1.4\left(\mathrm{~m}, 14 \mathrm{H},-7 \mathrm{CH}_{2} \text {-chain): }\right. \\
\delta 2.6-2.3\left(\mathrm{~m}, 4 \mathrm{H},-\mathrm{N}-\mathrm{CH}_{2} \mathrm{CH}_{2}-\mathrm{O}\right) ; \\
\delta \text { 3.8-3.5 }\left(\mathrm{m}, 36 \mathrm{H}, 9\left(\mathrm{CH}_{2} \mathrm{CH}_{2} \mathrm{O}\right) ; 7.8-7.4(\mathrm{~m}, 4 \mathrm{H}, \mathrm{ArH}) .\right. \\
\text { and } 4.4(\mathrm{~s}, 2 \mathrm{H}, \mathrm{OH})\end{array}$ & $\begin{array}{c}2890-2880 \mathrm{~cm}^{-1} v \mathrm{CH} \text { ali. } \\
3080-3020 \mathrm{~cm}^{-1} v \mathrm{CH} \text { of arom. } \\
1120-1100 \mathrm{~cm}^{-1} v \text { of } \mathrm{CH}_{2} \mathrm{OCH}_{2} \\
\mathrm{vSO}_{2} \text { at } 1050-1020 \mathrm{~cm}^{-1} \\
3450-3350 \mathrm{~cm}^{-1} v \mathrm{OH} \text {. }\end{array}$ \\
\hline XIIb: (C12, 7 EO) : & $\begin{array}{l}\delta 0.90\left(\mathrm{t}, 3 \mathrm{H} \text {,term. } \mathrm{CH}_{3}\right) ; \delta 1.6-1.2\left(\mathrm{~m}, 22 \mathrm{H},-11 \mathrm{CH}_{2} \text {-chain): }\right. \\
\left.\delta \text { 2.7-2.5 (m, } 4 \mathrm{H},-\mathrm{N}^{-} \mathrm{CH}_{2} \mathrm{CH}_{2}-\mathrm{O}\right) ; \\
\delta \text { 3.9-3.4 (m, } 28 \mathrm{H}, 7\left(\mathrm{CH}_{2} \mathrm{CH}_{2} \mathrm{O}\right) ; 7.8-7.4(\mathrm{~m}, 4 \mathrm{H}, \mathrm{ArH}) . \\
\text { and } 4.4-4.2(\mathrm{~s}, 2 \mathrm{H}, \mathrm{OH})\end{array}$ & $\begin{array}{c}2920-2880 \mathrm{~cm}^{-1} v \mathrm{CH} \text { ali. } \\
3080-3010 \mathrm{~cm}^{-1} v \mathrm{CH} \text { of arom. } \\
1180-1130 \mathrm{~cm}^{-1} v \text { of } \mathrm{CH}_{2} \mathrm{OCH}_{2} \\
\mathrm{vSO}_{2} \text { at } 1070-1030 \mathrm{~cm}^{-1} \\
3400-3350 \mathrm{~cm}^{-1} v \mathrm{OH} .\end{array}$ \\
\hline
\end{tabular}

were investigated to evaluate the possible application of these products in different industrial fields.

\section{Surface and interfacial tension}

Reduction of surface or interfacial tension is one of the most commonly measured properties of surfactants in a solution. Due to the amphiphilic structures of the prepared surfactants, It was suggested that a good measurement of efficiency is the amount of surfactant required to reduce the surface tension by $20-d y n e / c m$ and the minimum tension obtainable with the surfactant measured its effectiveness (Rosen, 2004). The values of surface and interfacial tensions of the prepared surfactants increased by increasing the number of the ethoxy group per molecule of product and also increased by increasing the hydrophobic part of the molecule (c.f. Tables 4-6).At the same time, the surface activities of the prepared compounds increased in the order of the reduction of surface and interfacial tension values (more surface activities) for the ethoxylated compounds produced by $\mathrm{K} 10$ clay $>\mathrm{SnCl}_{4}>\mathrm{KOH}$, i.e. it depends on the type of catalysts used, due to the fact that compounds prepared with K10 clay catalyst have a narrow range of distribution (Sallay et al., 2000).

\section{Cloud point}

Generally, the surfactants show higher cloud points than their aqueous solutions with particular hydrophobic group and an increased number of ethoxy group per molecule. This may be attributed to the fact that increased hydration of ethylene oxide oxygen with increased ethylene oxide chain length requires higher temperatures until phase separation occurs (Ahmed et al., 2002). (see Tables 4-6), which gave good performance in hot water.

\section{Foaming power}

In general, nonionic surfactants form low and unstable foam. It was reported that the foaming 
Table 4

Surface properties of the ethoxylated synthesized surfactants (catalyst $\mathrm{KOH}$ )

\begin{tabular}{|c|c|c|c|c|c|c|c|c|}
\hline \multirow[b]{2}{*}{ Compd } & \multirow[b]{2}{*}{$x+y$} & \multirow{2}{*}{$\begin{array}{c}\text { S. T } \\
0.1 \text { wt. } \% \\
\text { dyne/cm }\end{array}$} & \multirow{2}{*}{$\begin{array}{c}\text { I.F.T } \\
0.1 \text { wt. } \% \\
\text { dyne/cm }\end{array}$} & \multirow{2}{*}{$\begin{array}{c}\text { Cloud } \\
\text { point }{ }^{\circ} \mathrm{C} \\
1.0 \text { wt. } \%\end{array}$} & \multicolumn{2}{|c|}{$\begin{array}{l}\text { Foam height } 1.0 \text { wt. \% } \\
(\mathrm{mm})\end{array}$} & \multirow{2}{*}{$\begin{array}{c}\text { Wetting } \\
\text { time (sec). } \\
1.0 \text { wt } \% \text {. }\end{array}$} & \multirow{2}{*}{$\begin{array}{l}\text { Emul.S. } \\
20 \text { mmole: } \\
\text { min. sec }\end{array}$} \\
\hline & & & & & $0^{\circ} \mathrm{mm}$ & $5^{\circ} \mathrm{mm}$ & & \\
\hline Iva & 5 & 40 & 15 & $>100$ & 80 & 40 & 60 & 15 \\
\hline $\mathrm{IVb}$ & 7 & 41 & 16 & $>100$ & 80 & 35 & 65 & 14 \\
\hline IVc & 9 & 42 & 17 & $>100$ & 85 & 45 & 70 & 13 \\
\hline $\mathrm{Va}$ & 5 & 41 & 15 & $>100$ & 85 & 45 & 65 & 17 \\
\hline $\mathrm{Vb}$ & 7 & 42 & 16 & $>100$ & 90 & 35 & 65 & 15 \\
\hline Vc & 9 & 44 & 17 & $>100$ & 90 & 35 & 70 & 15 \\
\hline Via & 5 & 42 & 16 & $>100$ & 90 & 40 & 70 & 20 \\
\hline VIb & 7 & 43 & 17 & $>100$ & 95 & 45 & 70 & 18 \\
\hline Vic & 9 & 44 & 18 & $>100$ & 95 & 50 & 75 & 15 \\
\hline
\end{tabular}

Table 5

Surface properties of the ethoxylated synthesized surfactants $\left(\mathrm{SnCl}_{4}\right)$

\begin{tabular}{|c|c|c|c|c|c|c|c|c|}
\hline \multirow[b]{2}{*}{ Compd } & \multirow[b]{2}{*}{$x+y$} & \multirow{2}{*}{$\begin{array}{c}\text { S. T } \\
0.1 \text { wt. \% } \\
\text { dyne/cm }\end{array}$} & \multirow{2}{*}{$\begin{array}{c}\text { I.F.T } \\
0.1 \text { wt.\% } \\
\text { dyne/cm }\end{array}$} & \multirow{2}{*}{$\begin{array}{c}\text { Cloud } \\
\text { point }{ }^{\circ} \mathrm{C} \\
1.0 \text { wt.\% }\end{array}$} & \multicolumn{2}{|c|}{$\begin{array}{l}\text { Foam height wt. } 1.0 \% \\
(\mathrm{~mm})\end{array}$} & \multirow{2}{*}{$\begin{array}{c}\text { Wetting } \\
\text { time (sec). } \\
1.0 \text { wt } \% \text {. }\end{array}$} & \multirow{2}{*}{$\begin{array}{l}\text { Emul.S. } \\
20 \text { mmole: } \\
\text { min. sec }\end{array}$} \\
\hline & & & & & $0^{\circ} \mathrm{mm}$ & $5^{\circ} \mathrm{mm}$ & & \\
\hline VIla & 5 & 39 & 13 & $>100$ & 80 & 35 & 45 & 15 \\
\hline VIIb & 7 & 40 & 13 & $>100$ & 85 & 40 & 50 & 13 \\
\hline VIIC & 9 & 40 & 14 & $>100$ & 90 & 40 & 50 & 13 \\
\hline VIIIa & 5 & 39 & 13 & $>100$ & 90 & 40 & 45 & 12 \\
\hline VIIIb & 7 & 41 & 14 & $>100$ & 95 & 45 & 45 & 11 \\
\hline VIIIc & 9 & 41 & 14 & $>100$ & 95 & 45 & 50 & 11 \\
\hline $\mathrm{IXa}$ & 5 & 40 & 14 & $>100$ & 90 & 40 & 45 & 12 \\
\hline $\mathrm{IXb}$ & 7 & 41 & 16 & $>100$ & 95 & 40 & 50 & 11 \\
\hline IXc & 9 & 42 & 16 & $>100$ & 100 & 45 & 50 & 10 \\
\hline
\end{tabular}

Table 6

Surface properties of the ethoxylated synthesized surfactants (catalyst K10 clay)

\begin{tabular}{|c|c|c|c|c|c|c|c|c|}
\hline \multirow[t]{2}{*}{ Compd } & \multirow[t]{2}{*}{$x+y$} & \multirow{2}{*}{$\begin{array}{c}\text { S. T } \\
0.1 \text { wt. } \% \\
\text { dyne/cm }\end{array}$} & \multirow{2}{*}{$\begin{array}{c}\text { I.F.T } \\
0.1 \text { wt.\% } \\
\text { dyne/cm }\end{array}$} & \multirow{2}{*}{$\begin{array}{l}\text { Cloud } \\
\text { point }{ }^{\circ} \mathrm{C} \\
1.0 \text { wt. } \%\end{array}$} & \multicolumn{2}{|c|}{$\begin{array}{c}\text { Foam height } 1.0 \\
\text { wt. \% (mm) }\end{array}$} & \multirow{2}{*}{$\begin{array}{c}\text { Wetting time } \\
\text { (sec). } \\
1.0 \text { wt } \%\end{array}$} & \multirow{2}{*}{$\begin{array}{l}\text { Emul.S. } \\
20 \text { mmole: } \\
\text { min. sec }\end{array}$} \\
\hline & & & & & $0^{\circ} \mathrm{mm}$ & $5^{\circ} \mathrm{mm}$ & & \\
\hline $\mathrm{Xa}$ & 5 & 37 & 13 & $>100$ & 100 & 35 & 40 & 15 \\
\hline $\mathrm{Xb}$ & 7 & 37 & 13 & $>100$ & 100 & 35 & 45 & 15 \\
\hline$X_{c}$ & 9 & 38 & 14 & $>100$ & 110 & 40 & 50 & 14 \\
\hline Xia & 5 & 38 & 13 & $>100$ & 100 & 40 & 40 & 15 \\
\hline $\mathrm{XIb}$ & 7 & 38 & 14 & $>100$ & 110 & 45 & 40 & 13 \\
\hline XIc & 9 & 39 & 14 & $>100$ & 110 & 45 & 42 & 13 \\
\hline XIIa & 5 & 38 & 14 & $>100$ & 110 & 40 & 40 & 14 \\
\hline XIIb & 7 & 39 & 15 & $>100$ & 110 & 40 & 44 & 13 \\
\hline XIIC & 9 & 40 & 15 & $>100$ & 115 & 45 & 50 & 12 \\
\hline
\end{tabular}

$x+y=$ moles of EO. Surface and interfacial tensions $= \pm 0.1$ dyne/cm; Cloud point $= \pm 1{ }^{\circ} \mathrm{C} ;$ foam height $= \pm 2 \mathrm{~mm}$ Wetting time $= \pm 1$ sec; emulsion $= \pm 30 \mathrm{sec}$.

height of the prepared surfactants increases with an increment in both the ethylene oxide unit and hydrophobic part per molecule of surfactant (Ahmed et al., 2002) as in our prepared compounds. Also, the highest foam was observed for the compounds produced using the K10 clay catalyst, due to possessig higher surface activities (c. f. Table 4-6). Also, it can be seen that these compounds appear to have moderate foaming properties and each compound exhibited not only moderate foam production (measured in terms of the height of foam at zero time) but also low-foaming stability (measured in terms of the height after $5 \mathrm{~min}$ ). These effects may be due to the presence of both the sulphonamide group (Reinskje et al., 2004) and the branching in hydrophilic (two head hydrophilic) in our surfactant molecules, which considerably increase the area per molecule and produce a less cohesive force at the surface (Chi-chum and KengMing, 2008). 


\section{Wetting time}

The wetting time of the prepared surfactants was measured and the data are listed in Tables 4-6. It can be seen from the data that, all the products show a decrease in wetting time, where good wetting times are recorded with a small ethylene oxide content (Ahmed et al., 2002). The lowest wetting times were recorded for compounds produced using the k10 clay catalyst.

\section{Emulsifying properties}

Emulsion stability was measured using standard procedures. As shown in the data given in Tables 4-6, the emulsifying properties increase by decreasing the number of ethylene oxide units and also increase by increasing the alkyl chain (Amine et al., 2004). It was observed that the prepared ethoxylated compounds produced by K10 clay catalyst showed somewhat low emulsification times as compared to the ethoxylated product using $\mathrm{KOH}$ and higher than the one produced using $\mathrm{SnCl}_{4}$.

\subsection{Biodegradability}

A biodegradation die-away test in ordinary river water gave satisfactory results (Table 7 gives some data for tested compounds). Each experiment was repeated at least three times, and the results are reported as the averages of three values.

The biodegradation was expressed as the measurement of the surface tension with time (in days). The rate of degradation of these compounds depends on the size of molecule; bulky molecules diffuse through the cell membrane and its degradation is more difficult, this means that these compounds with lower moles of ethylene oxide are more degradable than those which contain higher moles of ethylene oxide (Falbe, 1987). In general, the products have a much higher rate of degradation ranging to about 95\% degradation taking around 6-7 days. It could also be shown that the biodegradation of the surfactants decreased by increasing the number of carbon atoms of the alkyl chain and regardless of the catalyst used in the ethoxylation process.

\subsection{Biological activity}

All the compounds prepared were screened for their activity against Gram-positive bacteria (Stophyloccus aureus, Bacillus subtilis, Bacillus cereus), Gram-negative bacteria (Pseudomonas aurignosa, Echerichia coli, Enterobacter aerogenes), as well as fungi (Aspergillus niger, Penicillium italicum, Fusarium oxysporum) using amoxicillin as reference. The results are listed in Tables (8 and 9).

It is apparent from the data listed in (Table 8) that some of the synthesized compounds showed antibacterial activity. From the data listed in Tables 8 and 9 , It can be seen that all the tested compounds exhibited good biological activities towards bacteria and Fungi; However, concerning the activity against

Table 7

Biodegradability of some of the prepared nonionic surfactants at the constant ethylene oxide units

\begin{tabular}{ccccccccc}
\hline Compd. & $\mathbf{n}$ & $\begin{array}{c}\mathbf{1}^{\text {st }} \\
\mathbf{d a y}\end{array}$ & $\begin{array}{c}\mathbf{2}^{\text {nd }} \\
\text { day }\end{array}$ & $\mathbf{3}^{\text {rd }}$ day & $\mathbf{4}^{\text {th }}$ day & $\begin{array}{c}\mathbf{5}^{\text {th }} \\
\text { Day }\end{array}$ & $\mathbf{6}^{\text {th }}$ day & $\mathbf{7}^{\text {th }}$ day \\
\hline Iva & 5 & 57 & 64 & 73 & 80 & 88 & 93 & - \\
VIla & 5 & 58 & 66 & 75 & 83 & 92 & 99 & - \\
Xa & 5 & 60 & 69 & 78 & 87 & 95 & - & - \\
Vb & 7 & 53 & 60 & 73 & 82 & 93 & 98 & - \\
VIIIb & 7 & 55 & 60 & 71 & 81 & 90 & 96 & - \\
XIb & 7 & 58 & 58 & 68 & 75 & 83 & 90 & - \\
Vlc & 9 & 54 & 62 & 69 & 77 & 83 & 88 & - \\
IXc & 9 & 52 & 60 & 66 & 72 & 80 & 86 & - \\
XIlc & 9 & 50 & 58 & 65 & 70 & 78 & 82 & - \\
\hline
\end{tabular}

$n$ : number of mole of EO. Error of calculations was: biodegradation rate $= \pm 1.0 \%$

Table 8

Antibacterial activity of the prepared compounds at constant EO units

\begin{tabular}{|c|c|c|c|c|c|c|}
\hline Compds. & $\begin{array}{c}\text { Stophyloccus } \\
\text { aureus s }\end{array}$ & $\begin{array}{l}\text { Bacillus } \\
\text { subtilis }\end{array}$ & $\begin{array}{l}\text { Bacillus } \\
\text { cereus }\end{array}$ & $\begin{array}{c}\text { Pseudomonas } \\
\text { aurignosa }\end{array}$ & $\begin{array}{c}\text { Escherichia } \\
\text { coli }\end{array}$ & $\begin{array}{c}\text { Enterobacter } \\
\text { aerogenes }\end{array}$ \\
\hline $\mathrm{IVb}$ & 6 & 8 & 10 & 8 & 13 & 11 \\
\hline $\mathrm{Vb}$ & 5 & 9 & 7 & 7 & 10 & 12 \\
\hline VIb & 13 & 12 & 13 & 11 & 12 & 10 \\
\hline VIIb & 12 & 9 & 10 & 11 & 8 & 9 \\
\hline VIIIb & 11 & 12 & 10 & 9 & 9 & 10 \\
\hline $\mathrm{IXb}$ & 14 & 13 & 12 & 13 & 11 & 11 \\
\hline $\mathrm{Xb}$ & 11 & 11 & 12 & 12 & 13 & 8 \\
\hline $\mathrm{XIb}$ & 13 & 10 & 7 & 9 & 10 & 9 \\
\hline XIIb & 8 & 12 & 10 & 11 & 11 & 10 \\
\hline Amoxicillin & 13 & 10 & 12 & 12 & 11 & 10 \\
\hline
\end{tabular}


Table 9

Antifungal activity of the prepared compounds at constant EO units

\begin{tabular}{cccc}
\hline Compds. & Aspergillus niger & Penicillium italicum & Fusarium oxysporum \\
\hline IVa & 9 & 8 & 7 \\
Va & 10 & 9 & 8 \\
Vla & 12 & 11 & 10 \\
IVb & 9 & 11 & 8 \\
Vb & 11 & 9 & 8 \\
VIb & 12 & 8 & 9 \\
VIIb & 9 & 10 & 11 \\
VIIlb & 10 & 12 & 10 \\
IXb & 13 & 9 & 10 \\
Xb & 11 & 10 & 8 \\
XIb & 10 & 9 & 10 \\
XIIb & 13 & 12 & 11 \\
Amoxicillin & 13 & 9 & 8 \\
\hline
\end{tabular}

Gram-positive bacteria compounds, VIb, IXb, and $\mathrm{Xb}$ showed excellent activity, whereas compound, $\mathrm{Vb}$ showed moderate activity. On the other hand, the Gram-negative bacteria also showed good responses to tested compounds. Compounds IXb showed the maximum activity, higher than that of amoxicillin. Compound IVb, VIb, and $\mathrm{Xb}$ exhibited excellent antibacterial activity towards Escherichia coli.

Concerning the data of antifungal activity in (Table 9), compounds Vla, XIIb showed excellent activity against all Fungi, and exhibited maximum activities even higher than the reference. In general, the data obtained from the microbiological screening showed that the prepared nonionic surfactants have good biological activity that in some compounds exhibited equal to and sometimes greater than those of the reference drugs used. (AL-Haiza et al.,2003).

\section{CONCLUSION}

The prepared sulphonamide nonionic surfactants from the most inexpensive chemical exhibited good surface activities and biodegradability rather than biological activities towards bacteria and fungi,especially the produced using K10 clay catalyst, and can be recommended for use in many industrial detergents, agricultural chemical manufacturing, in the treatment of textiles and paper and even as an inhibitor of corrosion. Also, biodegradability tests showed these compounds to be environmentally friendly.

\section{ACKNOWLEDGMENTS}

Origin of cultures: Botany Department, Faculty of Science, Benha University, Egypt.

\section{REFERENCES}

Ahmed MHM, El-Dougdoug WIA, Sallay P. 2002. Preparation and evaluation of surface active properties of oxypropylated aralkylsulphate. Journal of Olaj, Szappan, Kozmetika 51, 77- 80.

Ahmed MHM, Sallay P, Rusznak I, Farkas L. 1996. Determination of the average ethoxylation degree. Journal of Tenside Surfactants Detergents 33, 410-411.

Al-Haiza MA, Mostafa MS, El-Kady MY. 2003. Synthesis and Biological Evaluation of Some New Coumarin Derivatives. Molecules 8, 275-286.

Amin MS, Eissa AMF, Shaaban AF, El-Sawy AA, ElSayed R. 2004. New heterocycles having a double characters; as antimicrobial and surface active agents. Part 1: Nonionic compounds from fatty acid isothiocyanate. Grasas Y Aceites 55, 370-376.

Assassi N, Azira H, Tazerouti A. 2006. Recent progress in the manufacture of alkanesulfonates photosulfochlorination of single chain length $\left(\mathrm{C}_{12}-\right.$ $\mathrm{C}_{16}$ ) n-alkanes using $\mathrm{SO}_{2} \mathrm{Cl}$ at high conversion rates in pure phase and in presence of solvent. Journal of Surfactants and Detergents 9, 249-257.

Azira H, Assassi N, Tazerouti A. 2003. Synthesis of long chain alkanesulfonates by photosulfochlorination using sulfuryl chloride. Journal of Surfactants and Detergents 6, 55-59

Bailey FE Jr., Joseph VK. 1991. Alkylene Oxides and Their Polymers. Marcel Dekker, Inc., New York. Basel, 35, Ch. 7, p 205.

Braun AM, Maurette MT, Oliveros E. 1986. Technologies photochimiques, $1^{\text {st }}$ edn. Presses Polytechniques Romandes, Lausanne, p 337.

Chiu-Chun Lai, Keng-Ming Chen. 2008. Preparation and surface activity of polyoxyethylene-carboxylated modified Gemini surfactants. Colloids and Surfaces A: Physicochem. Eng. Aspects 320, 6-10.

Cohen AW, Rosen MJ. 1981. Wetting properties of nonionic surfactants of homogeneous structure. Journal of American Oil Chemist's Society (S \& D). 1062-1066.

Durham K. 1961. Surface Activity and Detrgency, MacMillan Co. Ltd. London.

Egorov NS. 1965. Microbe antagonists and Biological Assessment of their Antibiotics Activity, Moscow, Vysshaya Shkola Publishers (in Russia).

El-Sukkary MA, El-Sawy AA, El-Dib F. 1987. Synthetic Detergents from Crude rice bran oil. Hungarian Journal of Industrial Chemistry 15, 317-322.

Etre ET, Richard RE, Darid A. 1974. Biodegradable surfactants derived from corn starch. Journal of American Oil Chemist's Society 51, 486-491. 
Fainerman VB, Mobius D, Miller R. 2001. Surfactants: Chemistry, Interfacial Properties, Applications, Elsevier, Amsterdam-London-New York- OxfordParis - Shannon - Tokyo $1^{\text {st }}$ edn. Ch. 1. p 9.

Falbe J. 1987. Surfactants in Consumers Products, Springer-Verlag, Heidelberg New York London Pairs Tokyo, p. 149.

Findely A. 1963 Practical Chemistry" Longmans, London, 6th, 1040 .

Hreczuch W, Trathnigg B, Dziwinski E, Pyzalski K. 2001. Direct Ethoxylation of a Longer-Chain Aliphatic Ester. Journal of Tenside Surfactants Detergents 4, 167-173.

Maria S, Holmberg K. 2005. Synthesis, Stability, and Biodegradability Studies of a Surface-Active Amide. Journal of Tenside Surfactants Detergents 8, (4), 331-336.

Mousli RE, Amel T. 2007. Direct Method of Preparation of Dodecanesulfonamide Derivatives and Some Surface Properties. Journal of Surfactants and Detergents 10, 279-285.

Nico M van Os. 1998. Nonionic Surfactants Organic Chemistry, Surfactant Science Series" Marcel Dekker, INC, 72, Ch. 1, p 4-33.

Reinskje T, Thorsten S, Jan BFN Engberts. 2004. Aggregation behavior of $p$ - $n$-alkylbenzamidinium chloride surfactants. Journal of Colloid and Interface Science 276, 212-220.
Rosen JM. 2004. Surfactants and Interfacial phenomena. Third Edn. A John Wiley \& Sons, INC., Publication. P. 208.

Saito Y, Sato T, Anazawa I. 1989. Correlation between Distribution of oxyethylene chain and Physicochemical Properties of Nonionic Surfactants. Yakuzaigaku, 49, 180-183.

Sallay P, Bekássy S, Ahmed MH, Farkas L, Rusznák I. 1997 .A Novel Way for Hydroxyethylation by Clay Catalyst. Tetrahedron Letters 38, 661-664.

Sallay P, Ahmed MHM, Bekasy S, Farkas L, Vig A, Rusznak I. 2000. Molar Mass Distribution of Hydroxyethylation of aralkyl alcohols. Periodic Polytechnica Series Chemical Engineering 44, 95-110.

Sandler RS, Hemlock L. 1989 U.S.P.O., 0371271 B1S 4.

Sandler RS. 1991 U.S.P.O., 2028717.

Schönfeld N. 1967. Surface Active Ethylene Oxide Adducts. Pergamon press, Oxford p 25, 45.

Takeshi H. 1970. Studies of ester containing surfactant: Preparation and properties of sodium sulphalkanoates. Bulletin Chemical Society of Japan 43, 2236-2240. 